\title{
Argininosuccinate Synthetase Activity in Cultured Human Lymphocytes
}

\author{
Oksana Lockridge, ${ }^{1,2}$ Elaine B. Spector, ${ }^{1,3}$ and Arthur D. Bloom ${ }^{1,4}$
}

Received 8 Dec. 1975-Final 27 Sept. 1976

The activity of argininosuccinate synthetase (E.C. 6.3.4.5), a urea cycle enzyme, was measured in cultured human lymphocytes using a new radioactive assay. Control cells had a maximum specific activity of $15.7 \pm 8.7$ nmoles per hour per milligram of protein and an apparent $\mathrm{K}_{\mathrm{m}}$ for citrulline of $2 \times 10^{-4} \mathrm{M}$, whereas cells derived from a patient with citrullinemia had no detectable activity. A nutritional variant, selected out of the citrullinemic lymphocyte population by ability to grow in citrulline, had a maximum specific activity of $10.7 \pm 3.8$ nmoles/hr/mg and an apparent $\mathrm{K}_{\mathrm{m}}$ for citrulline of $2 \times 10^{-2} \mathrm{M}$. These measurements confirm the observation that citrullinemia is associated with a defect in argininosuccinate synthetase activity and provide further evidence that citrullinemia is expressed in cultured lymphocytes. The emergence of a nutritional variant with a partial defect in argininosuccinate synthetase enzyme suggests that this citrullinemic patient has a heterogeneous population of cells, some totally defective and others only partially defective in argininosuccinate synthetase. The new activity assay is described in detail.

KEY WORDS: argininosuccinate synthetase; citrullinemia; urea cycle; human lymphocyte lines.

This research was supported by a National Institutes of Health Training Grant (5-TO1GM-0071) and NIH Program Project Grant (2-PO1-GM-15419).

${ }^{ \pm}$Department of Human Genetics, University of Michigan Medical School, Ann Arbor, Michigan.

2 Present address: Department of Pharmacology, University of Michigan Medical School, Ann Arbor, Michigan.

${ }^{3}$ Present address: Mental Retardation Unit/Neuropsychiatric Institute, UCLA Medical School, Los Angeles, California.

${ }^{4}$ Present address: Department of Pediatrics, Division of Genetics, Columbia University, College of Physicians and Surgeons, New York. 


\section{INTRODUCTION}

Spector and Bloom (1973) have shown that the hereditary urea cycle disorder citrullinemia is expressed in lymphocytes, that is, the defect responsible for this disease, although primarily a defect in liver argininosuccinate synthetase activity (McMurray et al., 1963; Morrow et al., 1967; Mohyuddin et al., 1967), is reflected in the patient's cultured lymphocytes. In this article, we describe a direct assay for argininosuccinate synthetase activity in cultured lymphocyte lines from the same citrullinemic patient, as well as in several control lines.

We report here a new microassay for argininosuccinate synthetase in crude cell homogenates. Our assay measures the amount of ${ }^{14} \mathrm{C}$-argininosuccinate made from ${ }^{14} \mathrm{C}$-aspartate. The urea cycle steps pertinent to our assay are (1) the reaction catalyzed by argininosuccinate synthetase

$$
\text { citrulline }+ \text { aspartate }+\mathrm{ATP}+\mathrm{MgCl}_{2} \rightarrow \text { argininosuccinate }+\mathrm{AMP}+\mathrm{PP}_{\mathbf{i}}
$$

and (2) the utilization of argininosuccinate by argininosuccinate lyase in the reaction

$$
\text { argininosuccinate } \rightarrow \text { fumarate }+ \text { arginine }
$$

No inhibitor specific for argininosuccinate lyase was added because none is known other than the antibody (Bray and Ratner, 1971; Ratner, 1955). So little ${ }^{14} \mathrm{C}$-argininosuccinate accumulates under the conditions of the assay that argininosuccinate lyase is not saturated with respect to its substrate, and therefore the rate of degradation of argininosuccinate is negligible. Our assay has the advantages that it is technically easy to do, requires very little material (only $0.1 \mathrm{mg}$ cell lysate corresponding to $3 \times 10^{5}$ washed cells is used per assay), and is sensitive, easily measuring as little as 2 nmoles per hour per milligram of protein.

\section{MATERIALS AND METHODS}

[U- $\left.{ }^{14} \mathrm{C}\right] \mathrm{L}$-Aspartic acid was purchased from Amersham/Searle in a deoxygenated solution containing $2 \%$ ethanol. The specific activity was 224 $\mathrm{mCi}$ per mmole. A minor impurity, constituting $0.4 \%$ of any given aliquot, eluted from the Dowex 1-X8 acetate column in the same position (the void volume) as the product we were monitoring. This impurity gave an undesirable high background and therefore we routinely purified the ${ }^{14} \mathrm{C}$-aspartate before use. The purification procedure reduced the background from 20,000 $\mathrm{cpm}$ to $1500 \mathrm{cpm}$. Five milliliters of the above ${ }^{14} \mathrm{C}$-aspartic acid solution containing $250 \mu \mathrm{Ci}$ was applied to a $2-\mathrm{ml}$ Dowex 1-X8 acetate column equilibrated with $0.05 \mathrm{M}$ acetic acid, packed in a 5-ml pipette. Elution was with $0.05 \mathrm{~m}$ acetic acid. The first $60 \mathrm{ml}$ containing about 6 million cpm was dis- 
carded; the next $100 \mathrm{ml}$ was collected in a round-bottom flask, evaporated to dryness at $30 \mathrm{C}$ in a rotary evaporator, and redissolved in $5 \mathrm{ml}$ deionized water. After transfer to a glass vial, the purified ${ }^{14} \mathrm{C}$-aspartate was stored frozen. If the solution was kept at room temperature, a microorganism grew in it which degraded all the aspartate within a week. A second passage through a 2-ml column did not further reduce the background counts, nor did use of a larger column.

Stock solutions used in the assay were $0.5 \mathrm{M}$ tris-chloride, $p \mathrm{H} 7.9,0.5 \mathrm{M}$

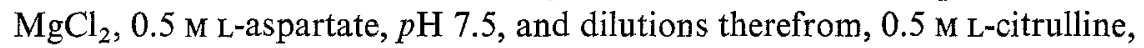

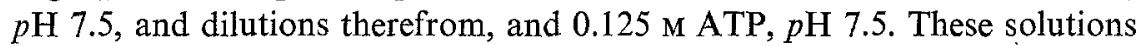
were stored frozen in small aliquots at $-20 \mathrm{C}$. Because ATP is unstable, unused portions of once-thawed solutions were discarded.

Dowex 1-X8, 200-400 mesh chloride form, was purchased from BioRad. The resin was converted to the acetate form by the method of Hirs et al. (1954) except that no precautions were taken to avoid ammonia adsorption. The resin was washed with water to remove the fines, then washed successively with $3 \mathrm{~m}$ sodium acetate, water, $0.5 \mathrm{M}$ acetic acid, and lastly 0.05 $\mathrm{M}$ acetic acid. For enzyme assays, 1-ml columns were packed just before use in disposable Pasteur pipettes. Once-used resin was discarded.

Scintillation fluid was made from Packard Co. scintillators by dissolving $0.10 \mathrm{~g}$ dimethyl POPOP and $4.0 \mathrm{~g}$ PPO in 1 liter reagent-grade toluene, then mixing in $500 \mathrm{ml}$ Triton X-100 (Rohm and Haas Co.). Fifteen milliliters of scintillation fluid was used with $1.5 \mathrm{ml}$ aqueous sample, or $10 \mathrm{ml}$ with $1 \mathrm{ml}$ aqueous sample. One-minute counts were taken on a Packard Tri-Carb liquid scintillation spectrometer model 3320. The counting efficiency was $97 \%$.

Lymphocyte lines were the same ones described by Spector and Bloom (1973) and Spector et al. (1975). University of Michigan long-term lymphocyte line 21 (UM 21) was established from a male patient with citrullinemia. One year later, ten single cell clones were isolated. The parent line was designated "UM 21 "; the ten clones were called "UM 21 clone 1," "UM 21 clone 2," etc. These lines grew exponentially in arginine-containing medium but were unable to survive in citrulline-containing medium. The lines which originated from citrullinemic cultures after 1-2 months of continuous incubation in citrulline-containing medium were called "variant" lines. The variants can grow in either arginine- or citrulline-containing medium but were maintained routinely in medium with $1 \mathrm{~mm}$ citrulline in place of arginine. The designations were "UM 21 variant," "UM 21 clone 2 variant," etc. The control lines tested were UM 1, UM 43, and UM 61 from male donors and UM 39, UM 55, and UM 56 from female donors. The controls were lymphocyte lines derived from people who did not have citrullinemia. All the control lines were maintained in Roswell Park Memorial Institute medium 1640 with 1 
$\mathrm{mM}$ arginine or $1 \mathrm{mM}$ citrulline, $20 \%$ fetal calf serum, penicillin, and kanamycin. The cells were harvested during logarithmic growth on the fourth day after subculturing. Cell viability at this time was about $90 \%$ as determined by trypan blue dye exclusion.

\section{Mycoplasma Testing}

All cell lines were tested for mycoplasma contamination by Dr. Leonard Hayflick, Department of Medical Microbiology, Stanford University School of Medicine, Stanford, California, and were found negative. As an additional precautionary measure, some of the cell lines were also checked by the Institute for Medical Research, Camden, New Jersey, and by the University of Michigan Hospital, Microbiology Laboratory, and were also found negative.

\section{Enzyme Assay}

The assay consisted of several distinct steps done on different days: cell harvesting, lysis and incubation in the reaction mixture were done on the first day, as many as 50 assays being easily done in 1 day; conversion of argininosuccinate to the anhydride was allowed to proceed for 2 days (or longer if this proved more convenient); the anhydride was separated from ${ }^{14} \mathrm{C}$-aspartate by chromatographing each sample on a 1-ml Dowex 1-X8 acetate column.

\section{Preparation of Cells}

Ten milliliters of cell suspension, with 6 million cells prior to washing, was centrifuged and washed once with $30 \mathrm{ml}$ cold saline. The cell pellet, now containing about 3 million cells which is equivalent to $1 \mathrm{mg}$ protein, was put on ice until use. This was enough for ten assays.

\section{Cell Lysis}

The enzyme lost activity rapidly once the cells were lysed; therefore, lysing was not done until the moment of assay. Lysis was achieved by suspending the cells in $1 \mathrm{ml}$ water, giving a $1 \mathrm{mg} / \mathrm{ml}$ solution, and freeze-thawing two times in dry ice-methanol. Freeze-thawing was necessary, for it was found that omission of this step reduced activity by $50 \%$. Aliquots were immediately pipetted into test tubes containing the reaction mixture. Care was taken to minimize the time which elapsed between additions of a given cell lysate to a series of test tubes. One-tenth milliliter of lysate was reserved for protein determination by the Lowry method. 


\section{The Reaction}

The reaction mixture contained - in a total volume of $0.5 \mathrm{ml}-10 \mathrm{~mm}$ tris- $\mathrm{Cl}$, $10 \mathrm{mM} \mathrm{MgCl}_{2}, 100$ or $20 \mathrm{~mm}$ L-citrulline, $0.2 \mathrm{~mm}$ L-aspartate, $5 \mathrm{~mm}$ ATP, 5 million cpm of ${ }^{14} \mathrm{C}$-aspartate, and $0.1 \mathrm{mg}$ crude cell lysate. The $p \mathrm{H}$ of this mixture when measured at room temperature was 7.5. The reaction was initiated by the addition of cell lysate. After a 1-br incubation at $37 \mathrm{C}$, the reaction was stopped by placing the tubes in a boiling water bath for $5 \mathrm{~min}$.

\section{Conversion to Anhydride}

To the boiled tubes, $0.05 \mathrm{ml}$ of $1 \mathrm{M}$ acetic acid was added. The contents were mixed in a Vortex stirrer and then incubated for 2 days in a $37 \mathrm{C}$ water bath. This procedure converted argininosuccinate to the anhydride.

\section{Chromatography}

Just before use, ten disposable Pasteur pipettes plugged with glass wool were packed with equilibrated Dowex 1-X8 acetate resin to a height of $4 \mathrm{~cm}$, to give $1-\mathrm{ml}$ columns. The entire sample from one test tube, including the denatured protein, was applied to a column and collected directly into a scintillation vial. The test tube was rinsed with $1 \mathrm{ml}$ of $0.05 \mathrm{M}$ acetic acid, and the rinse was applied to the same column and collected into the same vial. A second vial received the next $1.5 \mathrm{ml}$ of $0.05 \mathrm{M}$ acetic acid eluate. In these first two fractions, $99-99.5 \%$ of the anhydride eluted.

\section{Specific Activity}

Enzyme activity was expressed as nanomoles argininosuccinate produced per hour per milligram of protein where protein concentration was measured by the Lowry method.

\section{RESULTS}

\section{Argininosuccinate Synthetase Activity in Cultured Lymphocytes}

Argininosuccinate synthetase activity was measured in the citrullinemic cell line, in the nutritional variants, and in several control lines (Table I). The apparent $K_{m}$ for citrulline was measured by holding two substrates, ATP and aspartate, at saturating concentrations while citrulline concentration was varied over a range well below and above $K_{m}$. Figure 1a,b shows that observed activity increased linearly with increasing citrulline concentration 
Table I. Argininosuccinate Synthetase Activity in Cultured Lymphocytes

\begin{tabular}{lcccc}
\hline \multicolumn{1}{c}{ Cell line } & $\begin{array}{c}\text { Specific activity } \\
\text { at } 20 \mathrm{mM} \text { Cit }\end{array}$ & $\begin{array}{c}\text { Specific activity }^{a} \\
\text { at } 100 \mathrm{mM} \text { Cit }\end{array}$ & $\begin{array}{c}\text { Apparent } \\
K_{m}\end{array}$ & $\begin{array}{c}\text { Number of } \\
\text { times assayed }\end{array}$ \\
\hline Control & $15.7 \pm 8.7$ & $12.5 \pm 5.1$ & $2 \times 10^{-4} \mathrm{M}$ & 84 \\
Citrullinemic & 0 & 0 & $-\overline{10}$ & 41 \\
Variant & $4.9 \pm 2.0$ & $10.7 \pm 3.8$ & $2 \times 10^{-2} \mathrm{M}$ & 27 \\
Mouse & $646 \pm 103$ & & $4 \times 10^{-4} \mathrm{M}$ & 8 \\
\hline
\end{tabular}

${ }^{a}$ Nanomoles per hour per milligram of protein.
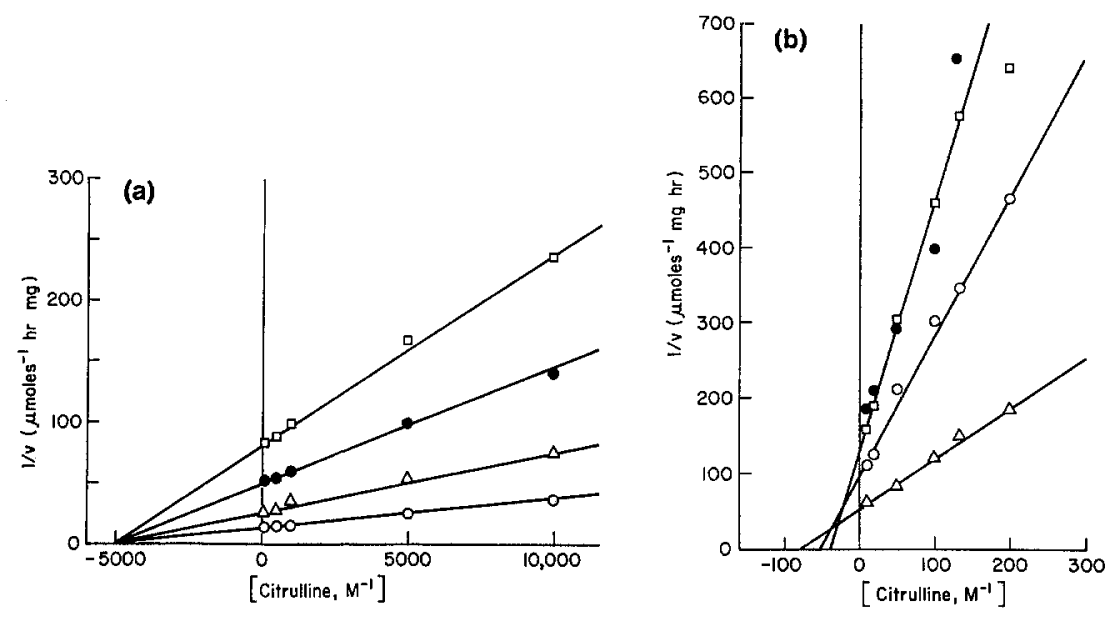

Fig. 1. Determination of apparent $K_{m}$ 's for citrulline of argininosuccinate synthetase in various lymphocyte lines. (a) Results for control lines. $\square$, UM 21 clone 6 grown in citrulline; $\bullet$, UM 43 grown in citrulline; $\triangle$, UM 21 clone 6 grown in arginine; 0, UM 43 grown in arginine. (b) Results for variant lines. •, UM 21 parent variant; $\square$, UM 21 clone 5 variant; $\bigcirc$, UM 21 clone 2 variant; $\triangle$, UM 21 clone 3 variant.

and that the control lines were saturated with respect to citrulline at $20 \mathrm{~mm}$ citrulline while the variants were saturated at $100 \mathrm{~mm}$ citrulline. The specific activities at these citrulline concentrations are therefore an approximation of maximal velocity $\left(V_{\max }\right)$. They deviate from $V_{\max }$ mainly because the incubations were for $1 \mathrm{hr}$, and Fig. 2 shows that the reaction rates had fallen off by about $15 \%$ at $1 \mathrm{hr}$. Table I shows that citrullinemic lymphocytes had no argininosuccinate synthetase activity whatsoever. No activity was detected even when the assay was run with the very high citrulline concentration of $0.3 \mathrm{M}$.

Of the ten clones, only one, clone 6 , had activity, and this activity was normal both in $K_{m}$ and specific activity. This exceptional clone was considered to be normal and not citrullinemic. Clone 6 was normal by other criteria: it 
Fig. 2. Argininosuccinate synthetase activity as a function of incubation time. Argininosuccinate synthetase activity was measured as described in Materials and Methods except that the total volume of reaction mixture was $3.5 \mathrm{ml}$. At the indicated time intervals, $0.5 \mathrm{ml}$ was removed and placed in a boiling water bath to stop the reaction.

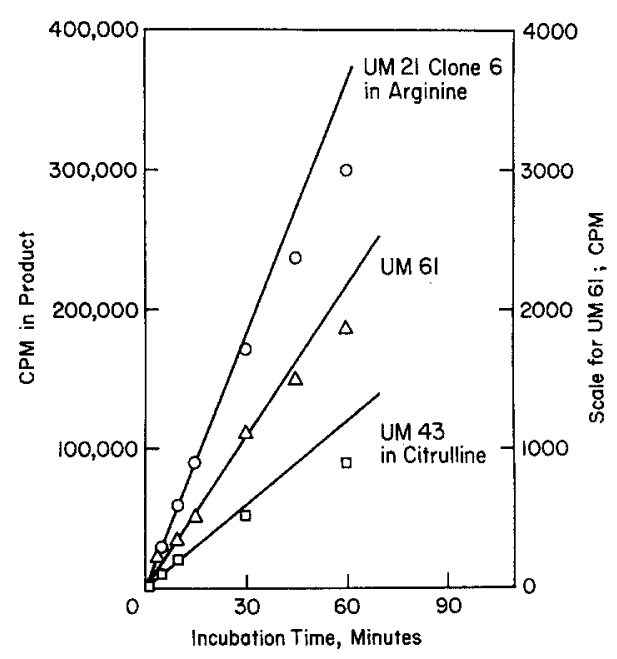

grew in citrulline-containing medium without undergoing the weeks of lag typical for the other clones; it took up ${ }^{14} \mathrm{C}$-citrulline from the medium and incorporated it into protein arginine at the same rate as did normal cells (Spector et al., 1975).

Argininosuccinate synthetase in all control lines had an apparent $K_{m}$ for citrulline of $2 \times 10^{-4} \mathrm{M}$. The $K_{m}$ value was an extremely reliable, reproducible number. $K_{m}$ was a better criterion for distinguishing control cells from variant cells than was specific activity, for, as Table I shows, the maximum specific activities for these cells were similar. Measurement of specific activity was an excellent method, however, to distinguish citrullinemic cells from all other cells, for the citrullinemic cells had zero activity.

Arginosuccinate synthetase in the variant lines typically had a much higher apparent $K_{m}$ for citrulline than in control lines. The variant $K_{m}$ s probably were not all an identical $2 \times 10^{-2} \mathrm{M}$; in fact, it is much more likely that if each variant line is the result of a different independent mutation the $K_{m}$ will differ slightly for each line. Because we were assaying crude homogenates, we did not have confidence in the small observed differences and therefore do not report them. Fresh lymphocytes from freshly drawn human blood had no activity.

\section{Enzyme Assay Method}

Linear Relationship Between Amount of Cell Lysate Used in Assay and Specific Activity

Since argininosuccinate is an intermediate in the urea cycle, it was important to choose conditions minimizing its degradation by argininosuccinate lyase. 


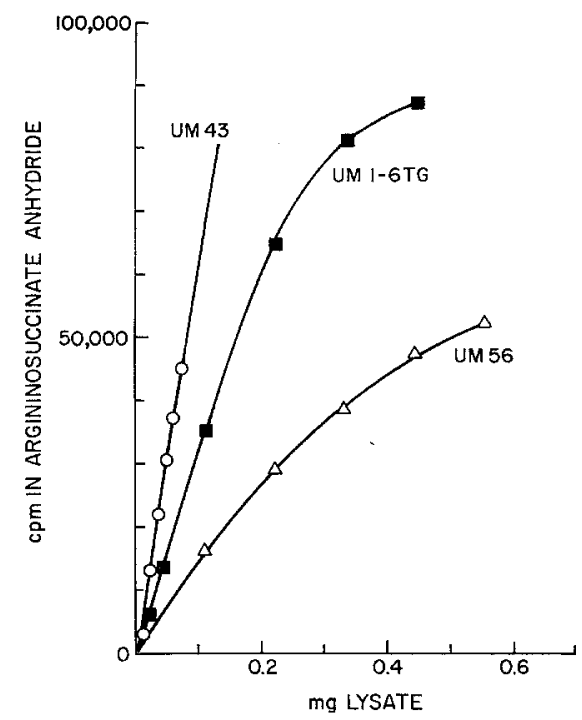

Fig. 3. Range of linearity between $\mathrm{mg}$ cell lysate used in assay and cpm in product. The assay is linear up to about $0.15 \mathrm{mg}$ cell lysate. Line UM 1-6TG is line UM 1 selected for growth in 6-thioguanine.

High concentrations of cell lysate would be expected to rapidly form as well as degrade argininosuccinate. Low concentrations of cell lysate would contain so little synthetase and lyase that it would be possible to saturate the synthetase with substrate without producing enough argininosuccinate for the very dilute lyase to encounter at a significant frequency. At low cell lysate concentrations, one could expect to find the amount of argininosuccinate isolated to be linearly related to the amount of cell lysate used in the assay. The experimental findings were as predicted (Fig. 3), showing a linear relationship when $0.025-0.15 \mathrm{mg}$ was used per assay, and a definite decline with $0.3 \mathrm{mg}$ or more. The optimal amount of protein per assay was found to be $0.1 \mathrm{mg}$.

In order to show that loss of argininosuccinate through action of argininosuccinate lyase was negligible, we measured ${ }^{14} \mathrm{C}$-fumarate, ${ }^{14} \mathrm{C}$-malate, and carbon dioxide. The label from argininosuccinate can go into fumarate and hence, through the citric acid cycle, into malate and carbon dioxide. We found negligible amounts of fumarate but did find malate and carbon dioxide when high concentrations of cell lysate were used or when an exceptionally active cell line such as the mouse line was assayed. These extremes defined the limits of our assay; one could not use as much as $0.4 \mathrm{mg}$ cell lysate per assay (the best amount to use is $0.1 \mathrm{mg}$ ) and the product should contain not more than about $100,000 \mathrm{cpm}$, i.e., $0.004 \mathrm{~mm}$. Under the conditions described in Materials and Methods, the loss of argininosuccinate through the action of lyase was negligible. 
Table II. Dependence of Argininosuccinate Formation on Added Citrulline ${ }^{a}$

\begin{tabular}{lc}
\hline \multicolumn{1}{c}{ Assay } & Cpm in product \\
\hline Complete & 135,417 \\
No citrulline & 0 \\
No ATP & 12,344 \\
No cell lysate & 0 \\
& \\
${ }^{a}$ Lysate from the control line UM 43 was \\
used.
\end{tabular}

\section{Dependence of Argininosuccinate Formation on Added Citrulline}

Because aspartate may potentially be metabolized into about 18 different compounds by entering the pyrimidine biosynthetic pathway and the citric acid cycle, it was important to prove that the radioactive compound with the characteristic elution properties of argininosuccinate was indeed argininosuccinate. This was done by measuring the dependence of formation of this compound on the presence of citrulline and of ATP. Table II shows that there is an absolute dependence on added citrulline for the formation of argininosuccinate. This confirms the identity of the compound, for orotic acid and other intermediates of pyrimidine biosynthesis would still have been made in the absence of added citrulline. That our product is not one of the citric acid cycle intermediates is demonstrated by the fact that the latter are all (with the exception of succinyl $\mathrm{CoA}$ ) di- and tricarboxylic acids and therefore would elute after aspartic acid rather than before it. In the absence of added ATP, some product was still formed, probably reflecting the presence of endogenous ATP. Another proof of identity is the fact that the assay product cochromatographed with commercial argininosuccinate, as well as with ${ }^{14} \mathrm{C}$-argininosuccinate made enzymatically with purified beef liver argininosuccinate synthetase.

\section{Anhydride Formation}

We decided to convert argininosuccinate to anhydride because some of the product in every reaction spontaneously converted to anhydride, necessitating inclusion of this peak in the total product counts, and because the anhydride eluted in a much smaller volume than did the acid, thus increasing the sensitivity of the assay. Complete conversion of argininosuccinate to anhydride was obtained by adding $0.05 \mathrm{ml} 1 \mathrm{M}$ acetic acid to the boiled $0.5 \mathrm{ml}$ reaction mixture and incubating at $37 \mathrm{C}$ for 2 days. If any argininosuccinate had remained in the acid form, it would have eluted immediately after the anhydride in the position shown in Fig. 4. 


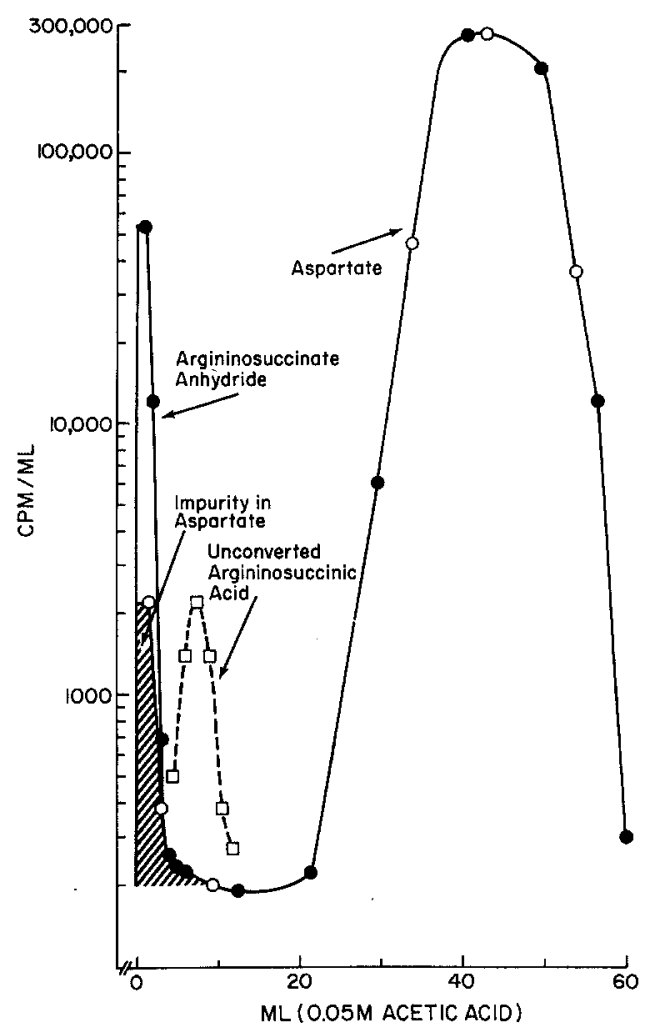

Fig. 4. Separation of argininosuccinate anhydride from L-aspartate on a 1-ml column. A 1-ml Dowex $1-\mathrm{X} 8$ acetate column was used to separate argininosuccinate anhydride from unreacted aspartate in a typical reaction mixture containing all the reactants described in Materials and Methods ( $\bullet$ ). The degree of resolution between anhydride and aspartate was extremely good, as $99 \%$ or more of the anhydride eluted in the first $3 \mathrm{ml}$ and aspartate began eluting only at $21 \mathrm{ml}$. In experiments carried out as described in Materials and Methods, no unconverted acid is present. This fact can be checked by collecting additional fractions, for unconverted acid ( $\square$ ) elutes just behind the anhydride. The contribution of the impurity in the ${ }^{14} \mathrm{C}$-aspartate to the total product counts was quantitated by running a control containing everything but cell lysate $(O)$. 
Conversion to anhydride might have been accomplished with the same efficiency in a much shorter time by boiling an acidified mixture. Ratner (1957) showed that, at $p \mathrm{H} 3.2,100 \%$ conversion to anhydride occurred in 30 min at $100 \mathrm{C}$.

\section{Activity as a Function of Incubation Time}

Activity up to $15 \mathrm{~min}$ incubation was linear and maximal, but thereafter it declined (Fig. 2). A 1-hr incubation gave about $85 \%$ of the specific activity seen initially. An incubation time of $1 \mathrm{hr}$ was chosen because in many instances mutants with very low activities, detection of which was possible only with prolonged incubation, were being assayed.

\section{Enzyme Stability}

Activity was rapidly lost when cells, lysed with water and two freeze-thawings, were kept at $37 \mathrm{C}$. The half-life at $37 \mathrm{C}$ in water was about $2 \mathrm{~min}$. On the other hand, the enzyme was quite stable in the assay mixture at $37 \mathrm{C}$, a 1-hr incubation giving $85 \%$ of the specific activity observed in a 5 - or 15 -min incubation. Such a rapid loss of activity would have made it impossible to carry out meaningful activity assays were it not for the finding that at $0 \mathrm{C}$ the enzyme was stable. If the freeze-thawed cells were immediately put on ice, they maintained a constant activity over the time required to pipette a series of tubes. The half-life at $0 \mathrm{C}$ in water was about $1 \frac{1}{2} \mathrm{hr}$.

\section{DISCUSSION}

The finding that our citrullinemic patient's lymphocytes completely lack argininosuccinate synthetase activity supports Spector's (Spector and Bloom, 1973; Spector et al., 1975) earlier observation that these same lymphocytes incorporated no ${ }^{14} \mathrm{C}$-citrulline into ${ }^{14} \mathrm{C}$-arginine in their protein and that they did not grow in medium in which citrulline had been substituted for arginine. Only three citrullinemic patients have to date been tested for argininosuccinate synthetase activity. Our patient is the only one with zero activity. Tedesco and Mellman (1967) found activity in fibroblasts from their citrullinemic patient. Kennaway et al. (1975) found activity in fibroblasts from yet another patient. Skin fibroblasts from our patient had no argininosuccinate synthetase activity (Scott-Emuakpor et al., 1972; Kennaway et al., 1975). Kennaway et al. (1975) assayed our citrullinemic lymphocyte line by a different method (Schimke, 1964) and also found zero activity.

Spector et al. (1975) have discussed the origin of the variant lymphocyte lines and concluded that they are cells with spontaneous back-mutations to partially active argininosuccinate synthetase selected out of the citrullinemic population by medium containing citrulline in place of arginine. The fact that 
variant-type cells were obtained from four clones and that argininosuccinate synthetase in them has an altered apparent $K_{m}$ for citrulline compared to normal cells is strong evidence that the mutation causing citrullinemia in this patient is a structural gene mutation. If $K_{m}$ is interpreted as reflecting substrate affinity, then the variant lines have a marked decrease in affinity for citrulline. It is equally likely that the $K_{m}$ s for ATP and aspartate are altered, but these were not measured.

Assays for argininosuccinate synthetase previously reported in the literature are of three types: (1) a colorimetric assay depending on either the disappearance of citrulline or the appearance of urea (Archibald, 1945; Koritz and Cohen, 1954; Ratner, 1955) is much too insensitive to detect activity in the very limited amounts of material present in cell culture; (2) a spectrophotometric kinetic assay linked to the utilization of NADH (Ratner, 1970) cannot be used for crude cell homogenates because the amount of citrulline-independent NADH oxidation present as background is so high that the small contribution from argininosuccinate synthetase activity cannot be detected; (3) a sensitive radioactive assay suitable for crude homogenates depends on the conversion of ${ }^{14} \mathrm{C}$-citrulline to ${ }^{14} \mathrm{C}$-urea by added excess argininosuccinate lyase and arginase (Schimke, 1964). This assay is difficult to carry out as there is no commercial source of lyase. The assay described in this communication is preferable because it directly measures the product of the enzyme reaction, it can be done with crude cell homogenates requiring little cell protein, and it is very sensitive. Kato et al. (1976) have published a similar assay for argininosuccinate synthetase in various rat organs.

\section{REFERENCES}

Archibald, R. M. (1945). Colorimetric determination of urea. J. Biol. Chem. 157:507.

Bray, R. C., and Ratner, S. (1971). Argininosuccinase from bovine kidney: Comparison of catalytic, physical, and chemical properties with the enzyme from bovine liver. Arch. Biochem. Biophys. 146:531.

Hirs, C. H. W., Moore, S., and Stein, W. H. (1954). The chromatography of amino acids on ion exchange resins: Use of volatile acids for elution. J. Am. Chem. Soc. 76:6063.

Kato, H., Oyamada, I., Mizutani-Funahashi, M., and Nakagawa, H. (1976). New radioisotopic assays of argininosuccinate synthetase and argininosuccinase. J. Biochem. $79: 945$.

Kennaway, N. G., Harwood, P. J., Ramberg, D. A., Koler, R. D., and Buist, N. R. M. (1975). Citrullinemia: Enzymatic evidence for genetic heterogeneity. Pediat. Res. 9:554.

Koritz, S. B., and Cohen, P. P. (1954). Colorimetric determination of carbamylamino acids and related compounds. J. Biol. Chem. 209:145.

McMurray, W. C., Rathbun, J. C., Mohyuddin, F., and Koegler, S. J. (1963). Citrullinuria. Pediatrics 32:347.

Mohyuddin, F., Rathbun, J. C., and McMurray, W. C. (1967). Studies on amino acid metabolism in citrullinuria. Am. J. Dis. Child. 113:152.

Morrow, G., Barness, L. A., and Efron, M. L. (1967). Citrullinemia with defective urea production. Pediatrics 40:565. 
Ratner, S. (1955). Enzymatic synthesis of arginine (condensing and splitting enzymes). Meth. Enzymol. 2:356.

Ratner, S. (1957). Preparation and determination of argininosuccinic acid. Meth. Enzymol. 3:643.

Ratner, S. (1970). Arginosuccinate synthetase. Meth. Enzymol. 17A:298.

Ratner, S., and Kunkemueller, M. (1966). Separation and properties of argininosuccinate and its two anhydrides and their detection in biological materials. Biochemistry 5:1821.

Rochovansky, O., and Ratner, S. (1961). Biosynthesis of urea. IX. Further studies on mechanism of argininosuccinate synthetase reaction. J. Biol. Chem. 236:2254.

Schimke, R. T. (1964). Enzymes of arginine metabolism in mammalian cell culture. I. Repression of argininosuccinate synthetase and argininosuccinase. $J$. Biol. Chem. 239:136.

Scott-Emuakpor, A., Higgins, J. V., and Kohrman, A. F. (1972). Citrullinemia: A new case with implications concerning adaptation to defective urea synthesis. Pediat. Res. 6:626.

Spector, E. B., and Bloom, A. D. (1973). Citrullinemic lymphocytes in Iong term culture. Pediat. Res. 7:700.

Spector, E. B., Lockridge, O., and Bloom, A. D. (1975). Citrulline metabolism in normal and citrullinemic human lymphocyte lines. Biochem. Genet. 13:471.

Tedesco, T. A., and Mellman, W. J. (1967). Argininosuccinate synthetase activity and citrulline metabolism in cells cultured from a citrullinemic subject. Proc. Natl. Acad. Sci. 57:829. 